\title{
OCCURRENCE OF Giardia CYSTS AND Cryptosporidium OOCYSTS IN ACTIVATED SLUDGE SAMPLES IN CAMPINAS, SP, BRAZIL
}

\author{
Luciana Urbano SANTOS(1), Taís Rondello BONATTI(2), Romeu CANTUSIO NETO(3) \& Regina Maura Bueno FRANCO(4)
}

\begin{abstract}
SUMMARY
Giardia and Cryptosporidium have caused several outbreaks of gastroenteritis in humans associated with drinking water. Contaminated sewage effluents are recognized as a potential source of waterborne protozoa. Due to the lack of studies about the occurrence of these parasites in sewage samples in Brazil, we compared the efficiency of two procedures for concentrating cysts and oocysts in activated sludge samples of one sewage treatment plant. For this, the samples were submitted to $i$ ) concentration by the ether clarification procedure (ECP) and to ii) purification by sucrose flotation method (SFM) and aliquots of the pellets were examined by immunofluorescence. Giardia cysts were present in all samples $(100.0 \%$; n $=8)$ when using ECP and kit 1 reagents, while kit 2 resulted in six positive samples $(85.7 \% ; \mathrm{n}=7)$. As for SFM, cysts were detected in $75.0 \%$ and $100.0 \%$ of these samples (for kit 1 and 2, respectively). Regarding Cryptosporidium, two samples (25.0\%; kit 1 and 28.5\% for kit 2) were detected positive by using ECP, while for SFM, only one sample (examined by kit 1) was positive (12.5\%). The results of the control trial revealed Giardia and Cryptosporidium recovery efficiency rates for ECP of $54.5 \%$ and $9.6 \%$, while SFM was $10.5 \%$ and $3.2 \%$, respectively. Considering the high concentration detected, a previous evaluation of the activated sludge before its application in agriculture is recommended and with some improvement, ECP would be an appropriate simple technique for protozoa detection in sewage samples.
\end{abstract}

KEYWORDS: Activated sludge; Cryptosporidium; Giardia; Ether clarification procedure; Sucrose flotation method.

\section{INTRODUCTION}

Human excrement can be a vehicle of various diseases and high concentrations of pathogens are often reported in raw sewage worldwide ${ }^{8}$.

Giardia and Cryptosporidium are protozoa that produce environmental stages (cysts and oocysts, respectively) that are eliminated in the feces of the host. These parasites are a common cause of acute gastroenteritis in humans and animals ${ }^{19,22}$, with human infection being usually acquired by direct contact between persons and by ingestion of contaminated food or water ${ }^{11,30}$.

In the first documented waterborne outbreak of human cryptosporidiosis in the $\mathrm{USA}^{6}$, sewage was implicated as a possible source of oocyst contamination. Another important case to be considered is the 1993 Milwaukee outbreak, which was assumed to have been caused by run-off from upstream cattle pastures but now human sewage has been recognized as the source of contamination ${ }^{25}$.

In Brazil, only $20 \%$ of municipalities collect and treat sewage before discharging it in the environment ${ }^{16}$. A very frequently used procedure in secondary sewage treatment is the activated sludge system, in which aerobic microorganisms degrade the organic matter present in raw sewage and the flocculated material is easily removed during the sedimentation stage ${ }^{13}$. Therefore, the activated sludge is the main byproduct of sewage treatment and its final disposal has been a matter of discussion in many countries ${ }^{5,17,20}$.

Data about the occurrence and concentration of cysts and oocysts in sewage in Brazil are scarce. One of the main reasons for this may be attributed to lack of adequate methodology for concentration of these parasites in sewage samples. Recent studies included microscopic evaluation without immunofluorescence assay (IFA) ${ }^{23}$ in sewage sludge, and the detection of cryptosporidial oocysts in raw sewage in the cities of Araras and São Paulo (state of São Paulo) ${ }^{7,10,21}$ by calcium carbonate flocculation and membrane filter dissolution methods, both with visualization of protozoan parasites by IFA.

Since the presence of these protozoa was registered in superficial raw water of the Atibaia River, the major water source in Campinas ${ }^{12}$, and that this river receives discharge of urban sewage ${ }^{1,18}$ by means of

(1) Pós-graduando, Curso de Pós-graduação em Parasitologia, Instituto de Biologia, Universidade Estadual de Campinas (UNICAMP), Campinas, SP, Brasil.

(2) Bolsista de Iniciação Científica da Fundação de Amparo à Pesquisa do Estado de São Paulo (FAPESP). Processo nº 02/128345-0

(3) Pós-graduando, Laboratório de Microbiologia, Sociedade de Abastecimento de Água e Saneamento S/A, Campinas, SP, Brasil.

(4) Professor Assistente-Doutor, Laboratório de Protozoologia, Departamento de Parasitologia, Instituto de Biologia, Unicamp, Campinas, SP, Brasil.

Correspondence to: Dra. Regina Maura Bueno Franco, Laboratório de Protozoologia, Depto. de Parasitologia, Instituto de Biologia, Universidade Estadual de Campinas, Caixa Postal 6109, 13083-970 Campinas, SP, Brasil. Fax: +55-19-32893124. E-mail: mfranco@unicamp.br 
the Pinheiros Stream, the detection of Giardia and Cryptosporidium in wastewater provides important clues for information on the environmental epidemiology of these parasites in this region. Thus, in order to determine the occurrence of Giardia and Cryptosporidium in wastewater samples, we compared the efficiency of two procedures for concentrating cysts and oocysts in activated sludge samples.

\section{MATERIAL AND METHODS}

The activated sludge samples were collected in sterilized plastic containers from the Santa Rosa sewage treatment plant (E.T.E. Santa Rosa), with a $7.79 \mathrm{~L} /$ minutes capacity, in Campinas. The present work was carried out in eight subsequent weeks.

These samples $(\mathrm{n}=8)$ were filtered through a $1 \mathrm{~mm}^{2}$ plastic sieve to remove large debris and the filtrate was split into two aliquots, further concentrated by the ether clarification procedure (ECP) and sucrose flotation method (SFM), according to ROBERTSON et al. $(2000)^{26}$, with modifications. Briefly, for ECP, aliquots of filtrate were diluted (1:3) in $1 \%$ Tween 80 solution and the pellets were retrieved by double centrifugation ( $15 \mathrm{~min} ; 1500 \mathrm{x} \mathrm{g}$ ) and further concentrated by using ether centrifugal sedimentation (ECP) (10 min; $1500 \mathrm{x} g$ ), after previous hand agitation $(30 \mathrm{sec})$. For SFM, after double centrifugation, saturated sucrose solution (s.g. $=1.20$ ) was added to the pellets and once more centrifuged during $15 \mathrm{~min}(1500 \mathrm{x} g)$. The superficial layer $(3 \mathrm{~mL})$ was collected and transferred to a clean tube. This procedure was repeated once again. The final washed concentrate samples were resuspended in $1.0 \mathrm{~mL}$ with distilled water and duplicate $5 \mu \mathrm{L}$ aliquots were examined using two different fluorescent monoclonal antibody tests (kit 1: Merifluor kit, Meridian Bioscience, Cincinnatti, Ohio and kit 2: Crypto/Giardia-Cel I. F. Test, CELLABS PTY LTD, Australia), according to the manufacturer's instructions, with the purpose of enumerating cysts and oocysts in the analyzed samples. Simultaneously, a confirmatory test was performed by inclusion of fluorogenic vital dye DAPI (4', 6'-diamidino-2-phenylindole, Sigma Chemicals) for visualization of morphologic characters (nucleus, axonemes or suture). These preparations were observed through a Zeiss Axiolab epifluorescence microscope, with excitation and barrier filters equipped with appropriate filter blocks for FITC and DAPI viewing (400 x).

A control trial was performed to evaluate recovery efficiency of the methods employed. For this, samples of effluent sewage previously determined negative by ECP and SFM methods were seeded with estimated numbers of Giardia cysts $\left(4.4 \times 10^{3}\right)$ and Cryptosporidium oocysts $\left(5.4 \times 10^{4}\right)$, using the well-slide counting technique ${ }^{9}$. These samples were analyzed by the same procedures described above. The detected cysts and oocysts in all samples are in conformity with standard fluorescence detection criteria ${ }^{15}$.

The estimate of the number of cysts and oocysts/L $(x)$ was calculated by the following formula ${ }^{3,9}$ :

$$
x=\left[\begin{array}{lll}
\frac{\mathrm{n}^{\circ} \text { of }(\mathrm{oo}) \text { cysts } \times 10^{6}}{\text { vol. of sample in well }} & \times \frac{\text { vol. of pellet }(1 \mathrm{~mL})}{\text { vol. of sample }(\mathrm{mL})}
\end{array}\right]
$$

Statistical analyses were carried out using the SAS (Statistical Analysis System) software. ANOVA was used to make comparisons among variables, using the GLM (general linear models) procedure ${ }^{29}$.

\section{RESULTS}

When using ECP, Giardia cysts were present in all activated sludge samples $(\mathrm{n}=8 ; 100.0 \%)$ from ETE Santa Rosa, which were examined with kit 1 reagents (Table 1), while kit 2 resulted in six positive samples $(85.7 \% ; \mathrm{n}=7)$. In turn, when using SFM, Giardia cysts were detected in $75.0 \%(n=8)$ and $100.0 \%(n=7)$ of these samples (for kit 1 and 2, respectively). Regarding cryptosporidial oocysts, two samples $(25.0 \%$ kit 1 ; and kit 2: $28.5 \%)$ were detected positive by using ECP, while for SFM, only one sample (examined by kit 1) was positive $(12.5 \%)$ (Table 2).

Analysis of variance $(\mathrm{p}=0.05)$ showed a significant difference between the methodologies for Giardia cyst recovery, with ECP being the most efficient. For Cryptosporidium detection, no significant differences were found between the procedures. Moreover, for both protozoa, there was no significant difference between the monoclonal antibody kits (Table 1).

A higher number of Giardia cysts/L was observed in samples stained with kit $1\left(4.0 \times 10^{4}\right.$ to $\left.1.2 \times 10^{6}\right)$ when compared to samples stained with kit 2 reagents $\left(4.0 \times 10^{4}\right.$ to $\left.4.4 \times 10^{5}\right)$ (Table 1$)$. For Cryptosporidium, a higher number of oocysts/L were observed with kit $1\left(4.4 \times 10^{4}\right.$ to $\left.8.0 \times 10^{4}\right)$ than with kit $2\left(4.0 \times 10^{4}\right)$ (Table 2).

Higher recovery efficiency was obtained in control trials using ECP (Giardia and Cryptosporidium recovery efficiency rates of $54.5 \%$ and $9.6 \%$, respectively) than by SFM (10.5\% for Giardia and 3.2\% for Cryptosporidium).

Both cysts and oocysts in positive samples showed apple-green fluorescence, although higher intensity was observed against the

Table 1

Number of Giardia cysts/L detected in activated sludge samples from Santa Rosa Sewage Treatment Plant (Campinas, Brazil) using two commercially available monoclonal antibodies* and two techniques (ECP and SFM) for enumeration and visualization of protozoan parasites

\begin{tabular}{|c|c|c|c|c|}
\hline \multirow[b]{3}{*}{ Sample } & \multicolumn{4}{|c|}{ Technique } \\
\hline & \multicolumn{2}{|c|}{ ECP } & \multicolumn{2}{|c|}{ SFM } \\
\hline & Kit 1 & Kit 2 & Kit 1 & Kit 2 \\
\hline I & $2.0 \times 10^{5}$ & - & 0 & - \\
\hline II & $8.0 \times 10^{4}$ & 0 & $1.6 \times 10^{5}$ & $8.0 \times 10^{4}$ \\
\hline III & $3.6 \times 10^{5}$ & $1.6 \times 10^{5}$ & $8.0 \times 10^{4}$ & $1.6 \times 10^{5}$ \\
\hline IV & $2.8 \times 10^{5}$ & $8.0 \times 10^{4}$ & $1.2 \times 10^{5}$ & $2.0 \times 10^{5}$ \\
\hline V & $1.2 \times 10^{6}$ & $3.6 \times 10^{5}$ & $8.0 \times 10^{4}$ & $2.4 \times 10^{5}$ \\
\hline VI & $8.4 \times 10^{5}$ & $3.2 \times 10^{5}$ & $6.0 \times 10^{5}$ & $4.0 \times 10^{4}$ \\
\hline VII & $8.8 \times 10^{5}$ & $3.2 \times 10^{5}$ & 0 & $1.2 \times 10^{5}$ \\
\hline VIII & $8.0 \times 10^{5}$ & $4.4 \times 10^{5}$ & $4.0 \times 10^{4}$ & $4.0 \times 10^{4}$ \\
\hline Mean & $5.8 \times 10^{5}$ & $2.4 \times 10^{5}$ & $1.35 \times 10^{5}$ & $1.25 \times 10^{5}$ \\
\hline SD & $4.0 \times 10^{5}$ & $1.6 \times 10^{5}$ & $1.95 \times 10^{5}$ & $7.8 \times 10^{4}$ \\
\hline
\end{tabular}

* Kit 1: Merifluor kit, Meridian Bioscience, Cincinnatti, Ohio; Kit 2: Crypto/ Giardia-Cel I.F. Test, CELLABS PTY LTD, Australia; (ECP): concentration by the ether clarification procedure; (SFM): purification by sucrose flotation method; 0 : absence; -: not determined. 
Table 2

Number of Cryptosporidium oocysts/L detected in activated sludge samples from Santa Rosa Sewage Treatment Plant (Campinas, Brazil) using two commercially available monoclonal antibodies* and two techniques (ECP and SFM) for enumeration and visualization of protozoan parasites

\begin{tabular}{lccccc}
\hline & \multicolumn{4}{c}{ Technique } \\
\cline { 2 - 3 } \cline { 5 - 6 } Sample & \multicolumn{2}{c}{ ECP } & & \multicolumn{2}{c}{ SFM } \\
\cline { 2 - 3 } \cline { 5 - 6 } I & Kit 1 & Kit 2 & & Kit 1 & Kit 2 \\
II & $4.0 \times 10^{4}$ & - & & 0 & - \\
III & 0 & $4.0 \times 10^{4}$ & & & 0 \\
IV & 0 & 0 & & 0 & 0 \\
V & 0 & $4.0 \times 10^{4}$ & & 0 & 0 \\
VI & 0 & 0 & & 0 & 0 \\
VII & 0 & 0 & & $8.0 \times 10^{4}$ & 0 \\
VIII & 0 & 0 & & 0 & 0 \\
Mean & $1.0 \times 10^{4}$ & $1.14 \times 10^{4}$ & & $1.0 \times 10^{4}$ & 0 \\
SD & $1.8 \times 10^{4}$ & $1.95 \times 10^{4}$ & & $2.8 \times 10^{4}$ & 0 \\
\hline
\end{tabular}

* Kit 1: Merifluor kit, Meridian Bioscience, Cincinnatti, Ohio; Kit 2: Crypto/ Giardia-Cel I.F. Test, CELLABS PTY LTD, Australia; (ECP): concentration by the ether clarification procedure; (SFM): purification by sucrose flotation method; 0 : absence; -: not determined.

background and other interfering material for oocysts when using kit 2 reagents, making their identification very easy when compared with the counterpart sample processed by kit 1 ; in contrast, cysts showed brighter green fluorescence when kit 1 staining was performed (Fig. $1 \mathrm{a} ; 1 \mathrm{~b})$.

\section{DISCUSSION}

Environmental pollution is becoming a global matter nowadays and issues like water contamination, lack of safe water or disposal of residues are problems that can lead to serious public health consequences. In Latin America, subterraneous and superficial water contamination due to deficiency of wastewater treatment systems is escalating ${ }^{14}$. In Campinas, only $14 \%$ of domestic sewage is treated ${ }^{27}$.

Due to the sample type examined in this study, which contains a great number of particulate materials, and because methodologies using filtration can be inadequate for these samples (due to rapid filter blockage $)^{10,26}$, we evaluated the applicability of two methods (ECP and SFM) for protozoa detection in activated sludge samples and a higher recovery was obtained when using ECP instead of SFM, which was also confirmed in control trials. Our results corroborate those from ROBERTSON et al. ${ }^{26}$, who concluded that ether clarification for detection of Giardia cysts yields consistently higher recoveries than sucrose flotation when the raw sewage samples were examined. We can infer that major drawbacks of SFM derive from cyst and oocyst losses during the sucrose purification phase.

Both parasites were found in this study but Giardia prevailed with a higher number of positive samples than Cryptosporidium, and at higher concentrations; these data agree with results reported by BUKHARI et al. ${ }^{2}$ and CARRARO et al. ${ }^{4}$.

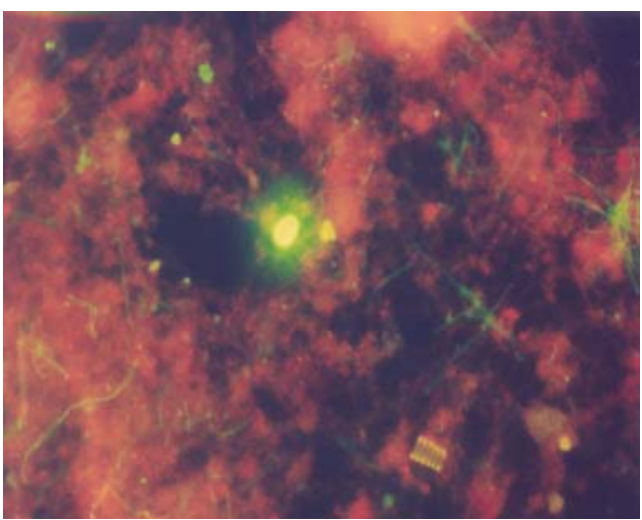

Fig. 1 - Giardia cyst, stained with kit 1 reagents, present in activated sludge samples of Santa Rosa ETE, Campinas, Southeast Brazil. 500x.

a)

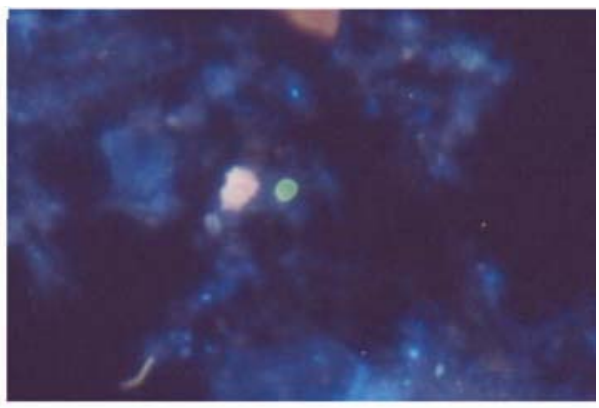

b)

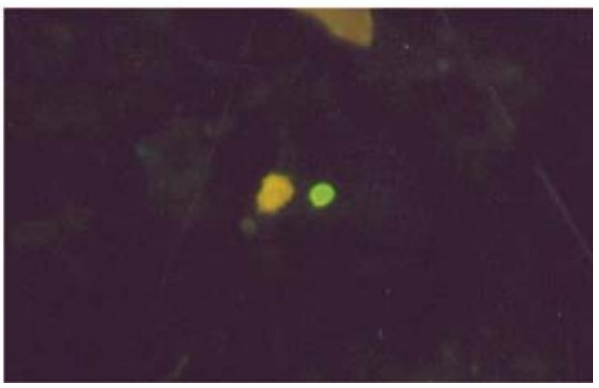

Fig. 2 - Cryptosporidium oocysts: a) stained with DAPI; b) stained with kit 2 reagents, present in activated sludge samples of Santa Rosa ETE, Campinas, Southeast Brazil. 500x.

Cyst and oocyst concentrations in raw and treated sewage appear to be highly variable: about $100-9200$ cysts/L and $1-560$ oocysts/L in samples of raw sewage or 2-898 cyst/L and 1-120 oocyst/L in treated sewage samples ${ }^{7,24}$, and up to $1.6 \times 10^{10}$ oocysts/L may be daily discharged from a treatment plant ${ }^{31}$. The high concentration of parasites observed in this study may be explained by the fact that the activated sludge process tends to concentrate them in the flocculated material ${ }^{28}$.

Although the statistical tests had not shown a significant difference between the kits, we observed better fluorescence quality for Cryptosporidium oocysts when kit 2 was used; as a result, the choice of antibody could be a personal choice.

The high concentration of cysts and oocysts found in activated sludge reinforces the necessity of residue evaluation before its final disposal in agriculture. Of all methods used in this study, ECP was the 
SANTOS, L.U.; BONATTI, T.R.; CANTUSIO NETO, R. \& FRANCO, R.M.B. - Occurrence of Giardia cysts and Cryptosporidium oocysts in activated sludge samples in Campinas, SP, Brazil. Rev. Inst. Med. trop. S. Paulo, 46(6):309-313, 2004.

most efficient in recovering Giardia and Cryptosporidium from activated sludge. However, other studies about the viability of cysts and oocysts found (through animal infectivity experiments) are necessary to evaluate the risks to Public Health, before choosing this type of reuse.

\section{RESUMO}

\section{Ocorrência de cistos de Giardia e oocistos de Cryptosporidium em amostras de lodo ativado em Campinas, SP, Brasil}

Giardia e Cryptosporidium causaram vários surtos epidêmicos de gastroenterite, associados à água potável. Efluentes de esgoto contaminados foram incriminados como uma fonte potencial de cistos e oocistos. Uma investigação foi conduzida para verificar a presença de cistos de Giardia e oocistos de Cryptosporidium em amostras de lodo ativado de uma Estação de Tratamento de Esgoto. Para isto as amostras foram submetidas: $i$ ) a concentração pelo processo de clarificação com éter (ECP) e ii) método de purificação por flutuação em sacarose (SFM) e, as alíquotas dos sedimentos foram examinadas por imunofluorescência. Cistos de Giardia estiveram presentes em todas as amostras avaliadas $(100,0 \% ; \mathrm{n}=8)$ quando utilizado ECP e kit 1, enquanto o kit 2 resultou em 6 amostras positivas $(85,7 \% ; \mathrm{n}=7)$. Para SFM, cistos de Giardia foram detectados em $75,0 \%$ e $100,0 \%$ destas amostras (para kit 1 e 2 respectivamente). Considerando os oocistos de Cryptosporidium, duas amostras (25,0\%; kit 1 e 28,5\% kit 2) foram positivas usando-se ECP enquanto para SFM, apenas uma amostra (examinada pelo kit 1) foi positiva (12,5\%). Os resultados do experimentocontrole revelaram que as taxas de recuperação para Giardia e Cryptosporidium, quando utilizado ECP foi de $54,5 \%$ e $9,6 \%$ e para SFM, foi de $10,5 \%$ e $3,2 \%$, respectivamente. Considerando a detecção de alta concentração desses protozoários, é recomendada a avaliação prévia do lodo ativado antes de sua aplicação na agricultura e, com alguma melhora, ECP pode ser uma técnica apropriada e simples para a detecção de protozoários em amostras de esgoto.

\section{REFERENCES}

1. BALLESTER, M.V.; MARTINELLI, L.A.; KRUSCHE, A.V. et al. - Effects of increasing organic matter loading on the dissolved $\mathrm{O}_{2}$, free dissolved $\mathrm{CO}_{2}$ and respiration rates in the Piracicaba river basin, Southeast Brazil. Water Res., 33: 2119-2129, 1999.

2. BUKHARI, Z.; SMITH, H.V.; SYKES, N.S.W. et al. - Occurrence of Cryptosporidium spp oocysts and Giardia spp cysts in sewage influents and effluents from treatment plants in England. Water Sci. Technol., 35: 385-390, 1997.

3. CANTUSIO NETO, R. \& FRANCO, R.M.B. - Ocorrência de oocistos de Cryptosporidium spp. e cistos de Giardia spp. em diferentes pontos do processo de tratamento de água, em Campinas, São Paulo, Brasil. Higiene Alimentar 18(118): 52-59, 2004.

4. CARRARO, E.; FEA, E.; SALVA, S. \& GILLI, G. - Impact of a wastewater treatment plant on Cryptosporidium oocysts and Giardia cysts occurring in surface water. Water Sci. Technol., 41: 31-37, 2000.

5. CORRÊA, R.S. \& CORRÊA, A.S. - Valoração de biossólidos como fertilizantes e condicionadores de solos. Sanare (Rev. Tec. Sanepar), 16: 49-56, 2001.

6. D'ANTONIO, R.G.; WINN, R.E., TAYLOR, J.P. et al. - A waterborne outbreak of cryptosporidiosis in normal hosts. Ann. intern. Med., 103: 886-888, 1985.

7. DIAS JÚNIOR, O. - Ocorrência de cistos de Giardia sp e oocistos de Cryptosporidium spp em águas superficiais e esgoto no município de Araras-SP. São Paulo, 1999. (Dissertação de Mestrado - Universidade Presbiteriana Mackenzie).
8. ENVIRONMENTAL PROTECTION AGENCY - Guidelines for water reuse. Washington, 1992. (EPA/625/R-92/004).

9. ENVIRONMENTAL PROTECTION AGENCY - E.P.A. Method 1623: Cryptosporidium and Giardia in water by filtration/IMS.FA. Washington, U.S. Environmental Protection Agency, 1999. (EPA 821 R99 - 006 April).

10. FARIAS, E.W.C.; GAMBA, R.C. \& PELLIZARI, V.H. - Detection of Cryptosporidium spp oocysts in raw sewage and creek water in the city of São Paulo, Brazil. Braz. J. Microbiol., 33: 41-43, 2002.

11. FAYER, R.; MORGAN, U. \& UPTON, S.J. - Epidemiology of Cryptosporidium: transmission, detection and identification. Int. J. Parasit., 30: 1305-1322, 2000.

12. FRANCO, R.M.B.; ROCHA-EBERHARDT, R. \& CANTUSIO NETO R. - Occurrence of Cryptosporidium oocysts and Giardia cysts in raw water from the Atibaia River, Campinas, Brazil. Rev. Inst. Med. trop. S. Paulo, 43: 109-111, 2001.

13. FREIRE, R.S.; PELEGRINI, R.; KUBOTA, L.T. \& DURAN, N. - Novas tendências para o tratamento de resíduos industriais contendo espécies organocloradas. Química Nova, 23: 504-511, 2000.

14. HEALTH NATIONAL FOUNDATION. Health Ministry; Brazil; Jun. 20, 2002. www.funasa.gov.br

15. HOFFMAN, R.; CHAURET, C.; STANDRIDGE, J. \& PETERSON, L. - Evaluation of four commercial antibodies. J. Amer. Water Works Ass., 91: 69-78, 1999.

16. INSTITUTO BRASILEIRO DE GEOGRAFIA E ESTATÍSTICA. PESQUISA NACIONAL DE SANEAMENTO BÁSICO Jun. 20, 2002. www.ibge.gov.br/home/ estatistica/populacao/condicaodevida/pnsb/default.shtm.

17. JIMÉNEZ, B.; MAYA, C.; SÁNCHEZ, E. et al. - Comparison of the quantity and quality of the microbiological content of sludge in countries with low and high content of pathogens. Water Sci. Technol., 46(10): 17-24, 2002.

18. KRUSCHE, A. V.; CARVALHO, F.P., MORAES, J.M. et al. - Spatial and temporal water quality variability in the Piracicaba river basin, Brazil. J. Amer. Water Res. Ass., 33: 1117-1123, 1997.

19. LLOYD, D. \& HARRIS, J.C. - Giardia: highly evolved parasite or early branching eukaryote? Trends Microbiol., 10: 122-127, 2002.

20. MELO, W.J.; MARQUES, M.O.; SANTIAGO, G. et al. - Efeito de doses crescentes de lodo de esgoto sobre frações da matéria orgânica e CTC de latossolo cultivado com cana de açúcar. Rev. bras. Cienc. Solo (Campinas), 18: 449-455, 1994.

21. MULLER, A.P.B. - Deteç̧ão de oocistos de Cryptosporidium spp em águas de abastecimento superficiais e tratadas da região metropolitana de São Paulo. São Paulo, 1999. (Dissertação de Mestrado - Universidade de São Paulo).

22. O'DONOGHUE, P.J. - Cryptosporidium and cryptosporidiosis in man and animals. Int. J. Parasit., 25: 139-195, 1995.

23. PAULINO, R.C.; CASTRO, E.A. \& THOMAZ-SOCCOL, V. - Tratamento anaeróbio de esgoto e sua eficiência na redução da viabilidade de ovos de helmintos. Rev. Soc. bras. Med. trop., 34: 421-428, 2001.

24. PAYMENT, P.; PLANTE, R. \& CEJKA, P. - Removal of indicator bacteria, human enteric viruses, Giardia cysts and Cryptosporidium oocysts at a large wastewater primary treatment facility. Canad. J. Microbiol., 47: 188-193, 2001.

25. PENG, M.M.; XIAO, L.; FREEMAN, A.R. et al. - Genetic polymorphism among Cryptosporidium parvum isolates: evidence of two distinct human transmission cycles. Emerg. infect. Dis., 3: 567-573, 1997.

26. ROBERTSON, L.J.; PATON, C.A.; CAMPBELL, A.T. et al. - Giardia cysts and Cryptosporidium oocysts at sewage treatment works in Scotland, UK. Water Res., 34: $2310-2322,2000$. 
SANTOS, L.U.; BONATTI, T.R.; CANTUSIO NETO, R. \& FRANCO, R.M.B. - Occurrence of Giardia cysts and Cryptosporidium oocysts in activated sludge samples in Campinas, SP, Brazil. Rev. Inst. Med. trop. S. Paulo, 46(6):309-313, 2004

27. SANASA - A SANASA hoje. Oct. 28, 2002. www.sanasa.com.br/_indexis.htm.

28. SANIN, D.F.; VESILIND, P.A. \& MARTEL, C.J. - Pathogen reduction capabilities of freeze/thaw sludge conditioning. Water Res., 28: 2393-2398, 1994.

29. SAS INSTITUTE - SAS User guide: Statistics, 6. North Carolina, Ed. Cary, 1986
30. THOMPSON, R.C. - Giardiasis as a re-emerging infectious disease and its zoonotic potential. Int. J. Parasit., 30: 1259-1267, 2000.

31. WHITMORE, T.N. \& ROBERTSON, L.J. - The effect of sewage sludge treatment processes on oocysts of Cryptosporidium parvum. J. appl. Bact., 78: 34-38, 1995.

Received: 17 November 2003

Accepted: 14 October 2004 